\title{
Purification of pyruvate kinase from pig dental pulp
}

\author{
Kenichi Ozawa, Kei Hirayama and Shozo Yamada \\ Department of Oral Biochemistry (Chief: Prof. Shozo Yamada), Josai Dental University, \\ Sakado, Saitama 350-02, Japan
}

[Accepted for publication: December 17, 1984]

Key words: purification / glycolysis / pyruvate kinase / pig dental pulp

\section{Introduction}

The purification of pyruvate kinase has been studied in various tissues ${ }^{1-3)}$ and the enzyme is known to have a regulatory function within the glycolytic pathway. It is thought that pyruvate kinase is one of the key enzymes in glycolysis and that the interactions of the enzyme with various modifiers are most important in controling the glycolytic rate. Enzymes involved in glycolysis in the dental pulp have been previously studied, such as lactate dehydrogenase ${ }^{4)}$, phosphofructokinase $^{5)}$ and pyruvate kinase ${ }^{6,7)}$. However, these enzymes were not completely purified.

In the present study pyruvate kinase has been purified from pig dental pulps.

\section{Materials and Methods}

Materials: Materials were purchased from the following sources: ADP, PEP and NADH, Oriental Yeast; lactate dehydrogenase, Beringer; phosphocellulose, Brown; and ampholine, LKB.

Dental pulps were separated from the lower jaws of freshly killed pigs obtained from the slaughter house. The pulps were stored frozen at $-80^{\circ} \mathrm{C}$ until use.

Enzyme assay. Pyruvate kinase activity was measured at $25^{\circ} \mathrm{C}$ in a coupled assay system similar to that described by Bücher and Pfleidere $^{8)}$. The assay mixture contained as final concentrations, $50 \mathrm{mM}$ Tris$\mathrm{HCl}$ buffer, $\mathrm{pH}$ 7.2, $100 \mathrm{mM} \mathrm{KCl}, 10 \mathrm{mM}$ $\mathrm{MgCl}_{2}, 0.5 \mathrm{mM}$ phosphoenolpyruvate, $1 \mathrm{mM}$ ADP, $0.15 \mathrm{mM} \mathrm{NADH}$, and $10 \mu \mathrm{g} / \mathrm{ml}$ of lactate dehydrogenase. The reaction was initiated by the addition of pyruvate kinase. Protein concentration was determined by the methods of Lowry et al..$^{9)}$ and Bensadoun and Weinstein ${ }^{10)}$. Polyacrylamide gel electrophoresis was carried out according to Davis ${ }^{11)}$. The gel concentration was $5 \%$ an $8-\mathrm{cm}$ length. Protein on the gel was stained with Coomassie brilliant blue.

\section{Results and Discussion}

Purification of pyruvate kinase.

Extract. Dental pulps were thawed, homogenized with 3 vols $(\mathrm{v} / \mathrm{w})$ of $10 \mathrm{mM}$ potassium phosphate buffer, $\mathrm{pH}$ 6.0, containing $5 \mathrm{mM} \mathrm{MgCl}_{2}, 5 \mathrm{mM}$ 2-mercaptoethanol, 0.2 $\mathrm{mM}$ fructose-1,6-diphosphate (FDP), and 1 mM EDTA (buffer A) in a Polytron-homogenizer at 10,000 r.p.m. for $30 \mathrm{sec}$. The supernatant fraction (crude extract) was collected by centrifugation of the homogenate at $18,000 \times \mathrm{g}$ for $30 \mathrm{~min}$.

Ammonium sulfate fractionation. Solid ammonium sulfate was added to the extract to make a concentration of $50 \%$ saturation. After being stirred for $30 \mathrm{~min}$, the supernatant fraction was collected by centrifugation at $18,000 \times \mathrm{g}$ for $30 \mathrm{~min}$. Solid ammonium sulfate was added to the supernatant to $70 \%$ saturation. After being stirred for $30 \mathrm{~min}$, the precipitate was collected by centrifugation $(18,000 \times \mathrm{g}, 30 \mathrm{~min})$ and dissolved in buffer $\mathrm{A}$.

Ammonium sulfate was removed from the protein fraction by gel filtration through a Sephadex G-25 column $(1.5 \times 12 \mathrm{~cm})$ equilibrated with buffer A.

Phosphocellulose column chromatography. 


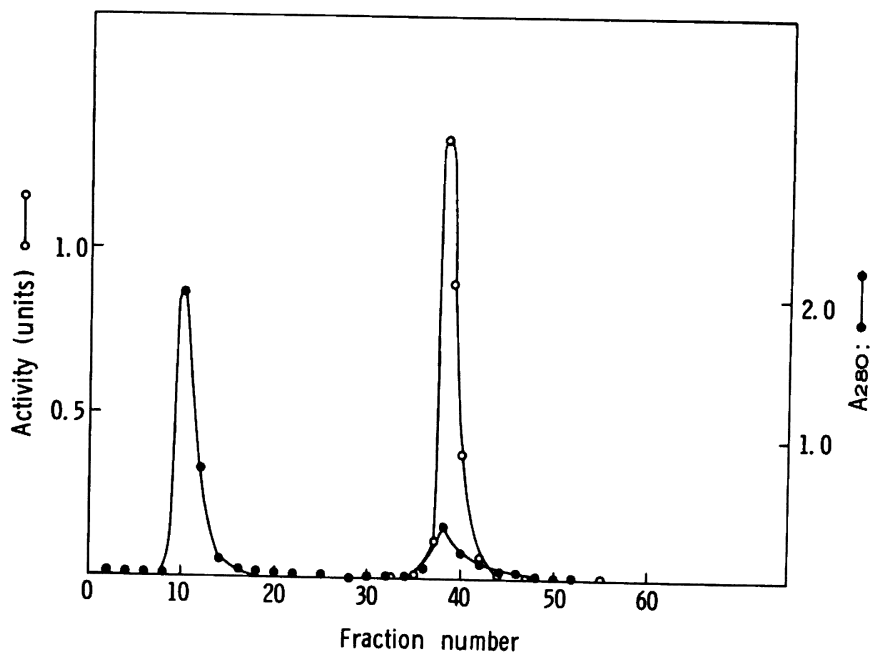

Fig. 1 Elution pattern of pig pulp pyruvate kinase on phosphocellulose column chromatography. Protein fraction $(5.0 \mathrm{ml})$ obtained by Sephadex G-25 gel filtration from $3 \mathrm{~g}$ of pig dental pulp was applied to phosphocellulose column $(1.5 \times 12$ cm) equilibrated with buffer A. After the column had been adequately washed the same buffer, the enzyme was eluted with a linear gradient $(0-500 \mathrm{mM} \mathrm{KCl})$ in the same buffer. $1-\mathrm{ml}$ fractions were collected.

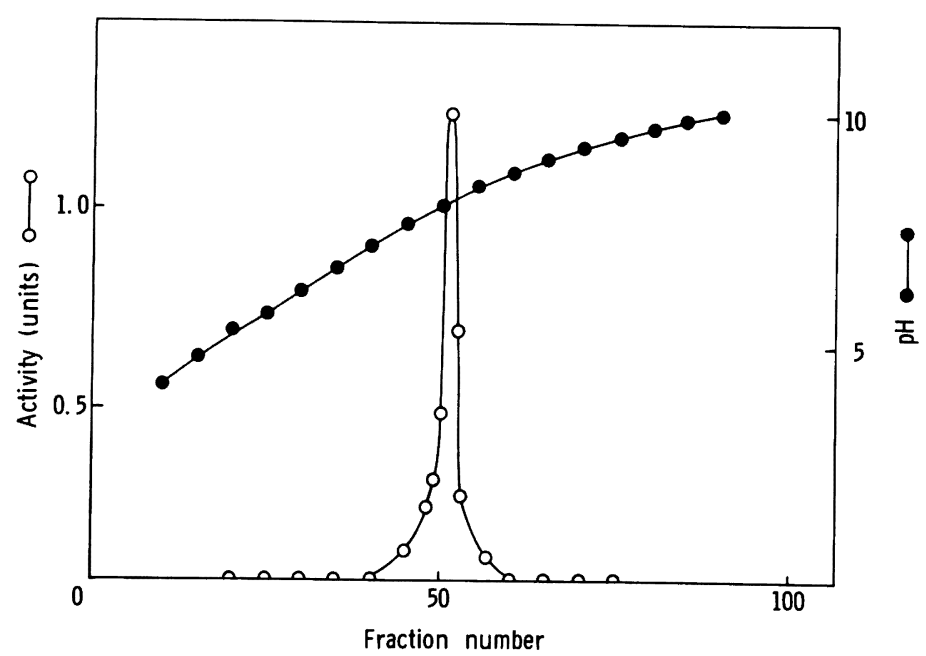

Fig. 2 Isoelectric fractionation of pyruvate kinase from pig dental pulp. Electrophoresis was performed at $700 \mathrm{~V}$ for $20 \mathrm{~h}$ at $0^{\circ} \mathrm{C}$.

The enzyme solution was applied to a phosphocellulose column $(1.5 \times 12 \mathrm{~cm})$ equilibrated with buffer $A^{11}$. After the column was washed with buffer A $(50 \mathrm{ml})$, the enzyme was eluted by a linear gradient of
$\mathrm{KCl}$ from 0 to $500 \mathrm{mM}$ in buffer $\mathrm{A}$. The flow rate was $30 \mathrm{ml} / \mathrm{h}$ and $2 \mathrm{ml}$ fractions were collected. Almost all of the enzyme activity was detected in 6 fractions (No. 3742) (Fig. 1). The active fractions were 
K. Ozawa, et al.: Purification of pyruvate kinase from pig dental pulp

Table 1 Purification step of pyruvate kinase from pig dental pulp

\begin{tabular}{|c|c|c|c|c|c|}
\hline Purification step & $\underset{(\mathrm{ml})}{\text { Volume }}$ & $\begin{array}{l}\text { Total protein } \\
\text { (mg) }\end{array}$ & $\begin{array}{l}\text { Total activity } \\
\text { (units) }\end{array}$ & $\begin{array}{l}\text { Specific activity } \\
\text { (units/mg) }\end{array}$ & $\begin{array}{c}\text { Yield } \\
(\%)\end{array}$ \\
\hline $\begin{array}{l}\text { Crude extract } \\
\left(\mathrm{NH}_{4}\right)_{2} \mathrm{SO}_{4} \text { fraction }\end{array}$ & 8.7 & 131 & 23.0 & 0.175 & 100 \\
\hline (50-70\% sat.) & 2.0 & 38.0 & 11.1 & 0.292 & 48.3 \\
\hline Phosphocellulose column & 10.8 & 0.607 & 5.05 & 8.32 & 22.0 \\
\hline Isoelectric focusing & 3.0 & 0.021 & 1.07 & 51.0 & 4.7 \\
\hline
\end{tabular}

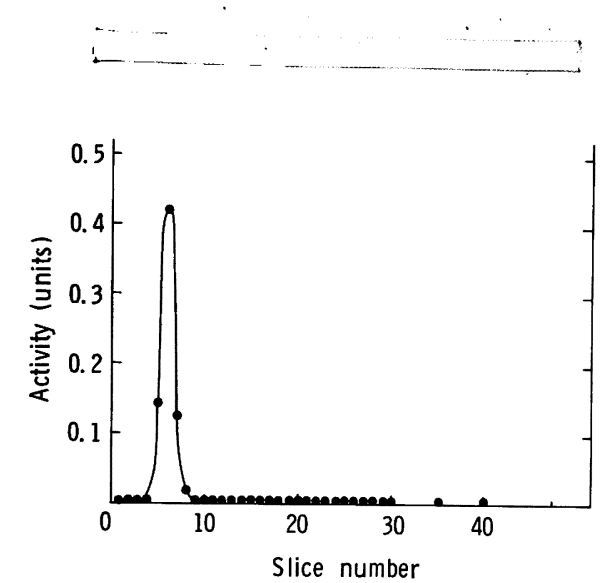

Fig. 3 Disk gel electrophoresis of pyruvate kinase on polyacrylamide gel. The purified enzyme ( $5 \mu \mathrm{g}$ ) was applied, and gel concentration was $5 \%$. Protein on the gel was stained with Coomassie brilliant blue. The enzyme activity was measured using $2 \mathrm{~mm}$ gel slices.

combined $(11 \mathrm{ml})$ and concentrated to about $2 \mathrm{ml}$ using a Collodion bag.

Isoelectric focusing. Isoelectric fractionation was carried out by the method of Verterberg and Svensson ${ }^{12)}$. Electrophoresis was performed at $700 \mathrm{~V}$ for $20 \mathrm{~h}$ at $0^{\circ} \mathrm{C}$. The maximal activity was detected at $\mathrm{pH}$ 8.0 (Fig. 2). The active fractions (No. 4951) were combined $(3 \mathrm{ml})$ and concentrated to about $0.5 \mathrm{ml}$ using a Collodion bag.

Electrophoresis. The purified enzyme gave a single protein band on polyacrylamide gel electrophoresis which coincided well with the position of enzyme activity revealed by assay of $2 \mathrm{~mm}$ gel slices (Fig. 3).

A summary of the purification procedure is presented in Table 1. Pyruvate kinase from pig dental pulp was purified to a homogeneous preparation which had a specific activity of 51 units $/ \mathrm{mg}$ of protein.

Pyruvate kinase has been purified from various tissues ${ }^{1-3)}$. However, the purification of the enzyme from dental pulp is quite difficult because dental pulps are small in size and surrounded by hard tissues. By using a phosphocellulose column and isoelectric focusing, pyruvate kinase has been purified from $3 \mathrm{~g}$ of dental pulp from 8 pigs in this study. This purified enzyme preparation will now be used to study the regulation of glycolysis in dental pulp.

\section{References}

1) Harada, K., Saheki, S., Wada, K. and Tanaka, T.: Purification of four pyruvate kinase isozyme of rats by affinity elution chromatography. Biochem. Biophys. Acta 524: 327339, 1978.

2) Nishimura, J., Hamasaki, N. and Minakami, S.: Platelet pyruvate kinase. Two interconvertible forms of the enzyme. Biochem. Biophys. Acta 522: 104-112, 1978.

3 ) Bergland, L. and Humble, E.: Kinetic properties of pig pyruvate kinase Type A from kidney and Type $M$ from muscle. Archs. Biochem. Biophys. 195: 347-361, 1979.

4) Roberts, R. W. and Strachan, D. S.: Quantitation of lactase dehydrogenase of developing molar teeth of the mouth. J. Dent. Res. 46: 522-526, 1967.

5) Ozawa, K.: Purification and kinetic properties of phosphofructokinase from rat dental pulp incisors. Archs. Oral Biol. (in press)

6) Ozawa, K., Hirayama, K., Yamada, S., Sato, N. and Goto, H.: Glycolysis in pig dental pulp. Bull. Josai Dent. Univ. 13(1): 18-22, 1984.

7) Nakamura, T., Fujii, M. and Kumegawa, M.: Isozyme of pyruvate kinase in the pulp 
from the rat incisor. Archs. Oral Biol. 19: 645-650, 1974.

8) Bücher, T. and Pfleider, G.: Pyruvate kinase from muscle. In: Methods in Enzymology, Colowick, S. P. and Kaplan, N. O., eds., Vol. 1, Academic Press, New York, pp. 435$440,1955$.

9) Lowry, O. H., Rosebrough, N. J., Farr, A. L. and Randall, R. J.: Protein measurement with the Folin-phenol reagent. J. Biol. Chem. 193: 265-275, 1951.

10) Bensadoun, A. and Weinstein, D.: Assay of proteins in the presence of interfering materials. Anal. Biochem. 70: 241-250, 1976.

11) Davis, B. J.: Disk electrophoresis II. Method and application to human serum proteins. Ann. N.Y. Acad. Sci. 121: 404-427, 1964.

12) Vesterberg, O. and Svensson, H.: Isoelectric fractionation, analysis and characterization of ampholytes in natural $\mathrm{pH}$ gradients- $\mathrm{N}$ : further studies on the resolving power in connection with separation of myoglobins. Acta chem. Scand. 20: 820-834, 1966. 